\title{
Management Innovation in Nanotechnology Sector: The First Insights in México
}

\author{
Juan Mejía-Trejo ${ }^{1}$, Zaira Yunuen Garcia-Carvajal ${ }^{2}$, Gilberto Israel González-Ordaz ${ }^{1}$ \\ ${ }^{1}$ Centro Universitario de Ciencias Económico Administrativas, University of Guadalajara \\ Periférico Norte $\mathrm{N}^{\circ} 799$, Núcleo Universitario Los Belenes, C.P. 45100, Zapopan, Jalisco, México \\ jmejia@cucea.udg.mx; juanmejiatrejo@hotmail.com \\ ${ }^{2}$ Pharmaceutical and Medical Biothecnology Unit \\ Av. Normalistas 800, Colinas de La Normal, 44270, Guadalajara \\ Centro de Investigación y Asistencia en Tecnología y Diseño del Estado de Jalisco, México \\ zgarcia@ciatej.mx
}

\begin{abstract}
Mexico, is an emerging economy that has a great opportunity to take advantage of the nanotechnology, because the Mexican government considers that is one of the key options for the growth of the economy (approach. 1.5 billion of usd per year in 2010), despite its modest number of companies (101) in the Nanotechnology Sector of Mexico (NSM), they are not enough competitive (COM) in nowadays. Additionally, since 2001the Mexican government has considered the investment in nanotechnology as a strategic niche that should be subject of support, making its first efforts through Universities and Research Centers. If we considered that Management of Innovation (MIN) is a key factor of competitiveness (COM), we could implement it for instance, to improve the relationships between these institutions and the companies of the NSM.

Hence, our research question is: What is the conceptual model of the MIN in the companies belonging to the NSM, to get more COM? To achieve this, we propose an exploratory, descriptive, and transversal research based on a documentary study to select the main variables among specialist in NSM practicing the MIN processes. We applied the analytic hierarchy process (AHP) as a qualitative method, to determine variables and a proposal of questionnaire in Likert scale, that shall be applied during May.-Dec.2017 to the total main managers of NSM companies. As a quantitative methods shall be applied are: Exploratory Factor Analysis (EFA) as a reduction of variables method, Multiple Linear Regression (MLR) as a predictive method, Cluster Analysis (CAN) to identify the representatives groups in the practice of MIN, and finally, Partial Least Squares regression (PLS) to disclose the underlying factors for the conceptual model.
\end{abstract}

As a conclusion at this stage, we show the conceptual model based on 3 factors (MIN, COM, NSM) and 29 variables with their indicators.

Keywords: Conceptual Model, Management of Innovation, Nanotechnology Sector, Competitiveness, Mexico

\section{Introduction.}

The nanotechnology in nowadays, is considered as a key factor to create several different business opportunities due its technological capability to develop a myriad of new products, and therefore, to make the companies more competitive [1]. Thus, the interest of governments, companies, international firms, consumer organizations, researchers and other actors to manage the nanotechnology [2].Since 2001, the Mexican government has recognized the nanotechnology sector (NSM) as a strategic area in its science and technology policies [3].

In this sense, Mexico ranks second in the development of nanotechnology in Latin America, after Brazil and followed by Argentina[4]. Currently, in Mexico, it's considered an strategic sector (approach. 1.5 billion of usd per year in 2010, [5]). There are 101 companies of nanotechnology working in different sectors, such as: chemistry (17), water (8), electric components (8), plastic and rubber (8), building trade (7), commerce (6), food (5), nanomaterials (5); industrial equipment (4), electronics (4), steel and iron (4), automobile (3), biotechnology (3), cosmetics (3), pharmacy (2), biomedic (2), home appliance (2), machinery (2), odontology equipment (2), mining (2), paper (1),Petrochemistry (1), cleaning services(1), textile (1) [2]. In 2006, CONACYT (National Science and Technology Council) in Mexico outlined the creation of two national laboratories with a budget of 2 million USD each (one in Chihuahua, the Centre of Advanced 
Materials Research -CIMAV-, and another Research Centre in San Luis Potosi) and established projects in strategic areas through finance allocated to five institutions in the amount of 10,000 USD each, among others the National Autonomous University of Mexico (UNAM), and the Centre for Research and Advanced Studies of the National Polytechnic Institute (CINVESTAV-IPN). The Special Program on Science and Technology of Mexico, corresponding to both 2001-2006 and 2008-2012, identified the nanotechnology as a strategic niche that should be subject of support.[6]. Thus, it is necessary to propose a model of MIN that allows more efficient the processes and increase the competitiveness of companies within the NSM.

\section{Problem and Rationale of the Study}

The problem is the settlement of a model capable to drive the relationships between the MIN to get more COM into the companies of NSM. Hence our research question (RQ) is: What is the conceptual model of the MIN in the companies belonging to the NSM, to get more COM?. The rationale of the study is due the NSM is interested to know which are the main variables of MIN related to get more efficient processes and increase the COM of their companies. The Specific Questions (SQ): SQ1.-What are the main variables and indicators more appropriated to describe the MIN, NSM and COM factors?; SQ2.-What is the proposed general conceptual model?; SQ3.-What is the proposal of questionnaire to be developed at a later stage?

\section{Literature Review}

The Competitiveness (COM). Competitiveness is the ability and performance of a company, sub-sector or country to sell and supply goods and services in a given market, in relation to the ability and performance of other firms, sub-sectors or countries in the same market [1],[7]. As a part of the Quality National Prize (Premio Nacional de Calidad) Mexico has designed its own National Competitiveness Model [8] adopted here in this study, with the following independent variables showed in Table 1.

Table 1. National Competitiveness Model.

\begin{tabular}{|c|c|c|}
\hline Item & Variable & Description \\
\hline 1 & $\begin{array}{l}\text { Leadership Transformer } \\
\text { (LDT) }\end{array}$ & $\begin{array}{l}\text { Leaders reflect on their behaviours and commitment to achieve the mission of organization, } \\
\text { change and innovation; they communicate with their staff, motivate them in their development } \\
\text { and overall well-being; they are aware of and responds to their own growth opportunities. }\end{array}$ \\
\hline 2 & $\begin{array}{l}\text { Customer Value Generation } \\
\text { (CVG) }\end{array}$ & $\begin{array}{l}\text { The organization knows its clients intimately, knows what creates its value and responds with } \\
\text { innovative proposals that ensure a memorable experience, follow the evolution of their needs } \\
\text { and establish the basis for a constant alignment with them }\end{array}$ \\
\hline 3 & Strategic Planning (STP) & $\begin{array}{l}\text { The organization ensures the fulfilment of its vision and mission; analysing their environment, } \\
\text { understanding their challenges, setting priorities, defining strategic objectives, aligning their } \\
\text { resources and capabilities to ensure their execution, monitoring and evaluating expected } \\
\text { results }\end{array}$ \\
\hline 4 & $\begin{array}{l}\text { Guidance to change, } \\
\text { innovation and continuous } \\
\text { development (CICD) }\end{array}$ & $\begin{array}{l}\text { The values of the organization lay the foundation for developing a culture focused on change, } \\
\text { innovation and continuous improvement that is reflected in the way staff organize and engage } \\
\text { to generate new ideas to respond to the challenges they face }\end{array}$ \\
\hline 5 & Social Commitment (SCO) & $\begin{array}{l}\text { The organization assumes responsibility for the social and environmental environment in } \\
\text { which it operates. This commitment is reflected in its initiatives to reduce its environmental } \\
\text { footprint, promote the integral well-being of its personnel and respond to the social needs of } \\
\text { its community. }\end{array}$ \\
\hline 6 & $\begin{array}{l}\text { Wellness and Inclusion } \\
\qquad(\mathbf{W} \& \mathbf{I})\end{array}$ & $\begin{array}{l}\text { The organization ensures the integration of all its staff through the creation of a shared identity } \\
\text { and responding to their physical and emotional needs in the workplace as well as in the } \\
\text { communities where they live }\end{array}$ \\
\hline 7 & Knowledge (KNW) & $\begin{array}{l}\text { The organization collects, organizes, shares and analyses knowledge through the use of its } \\
\text { resources and the skills of its staff, thereby generating the intellectual capital of the } \\
\text { organization it capitalizes for the improvement and innovation of its products, services and } \\
\text { processes. }\end{array}$ \\
\hline 8 & Agility (AGY) & $\begin{array}{l}\text { The organization responds quickly, adaptively and flexibly to the changes that occur in its } \\
\text { internal and external environment. }\end{array}$ \\
\hline
\end{tabular}


The Management of Innovation (MIN). The competitiveness recognizes the potential of the innovation which is defined as a: implementation of a new or significantly improved product (good or service), or process, a new marketing method, or a new organisational method in business practices, workplace organisation or external relations and it involves the innovation of: product, service, marketing, process and organization [9]. So, the importance to get a model for MIN that is defined as a set of tools for managers to design and implement with a common understanding of processes and goals for a company. It allows the organization to respond to external or internal opportunities, and use its creativity to introduce new ideas, processes or products [10],[11]. By utilizing the set of tools, MIN can trigger and deploy the creative capabilities of the work force for the continuous development of a company. It is not relegated only to R\&D; it involves workers and managers at every level, contributing creatively to a company's product development, manufacturing and marketing. Common tools may include since: brainstorming, virtual prototyping, product lifecycle management, idea management until TRIZ, QFD, Phase-gate model, project management, product line planning and portfolio management, etc. According the European Commission Directorate-general for Enterprise [12], we have 10 groups of MIN techniques with more than 40 particular techniques showed in Table 2.

Table 2. Management Innovation Techniques.

\begin{tabular}{|c|c|c|}
\hline Item & $\begin{array}{c}\text { Name of Innovation } \\
\text { Management Techniques Group }\end{array}$ & Particular Techniques \\
\hline (1) & $\begin{array}{l}\text { Knowledge Management } \\
\text { Techniques (KMT) }\end{array}$ & $\begin{array}{l}\text { (1)Knowledge Audit; (2)Knowledge Mapping; (3)Document Management System; } \\
\text { (4)Intellectual Property Rights }\end{array}$ \\
\hline (2) & $\begin{array}{l}\text { Market Intelligence Techniques } \\
\text { (MIT) }\end{array}$ & $\begin{array}{l}\text { (5)Technology Watch; Patent } \\
\text { Analysis;(6) CRM } \quad \text { (Customer Relationship } \\
\text { Management); (7)Geo-Marketing; (8) BIS (Business Intelligence Systems) }\end{array}$ \\
\hline (3) & $\begin{array}{l}\text { Cooperative and Networking } \\
\text { Techniques (C\&NT) }\end{array}$ & $\begin{array}{l}\text { (9)Team-Building Approaches;(10)Groupware Technologies;(11)SCM (Supply Chain } \\
\text { Management); (12) Industrial Clustering }\end{array}$ \\
\hline (4) & $\begin{array}{l}\text { Human Resources Management } \\
\text { Techniques (HRMT) }\end{array}$ & $\begin{array}{lcccc}\text { (13) Online Recruitment } & \text { Tools;(14) } & \text { Corporate Intranets;(15) } & \text { Teleworking } \\
\text { Techniques; (16) e-Learning Techniques;(17) Groupware Tools } & \\
\end{array}$ \\
\hline (5) & $\begin{array}{l}\text { Interface Management Techniques } \\
\text { (IMT) }\end{array}$ & (18) Concurrent Engineering;(19) R\&D/Marketing Interface \\
\hline (6) & $\begin{array}{l}\text { Creativity Development } \\
\text { Techniques (CDT) }\end{array}$ & $\begin{array}{l}\text { (20)Brainstorming; Lateral Thinking; (21) TRIZ (Inventive Problem-solving); } \\
\text { (22)SCAMPER method; (23)Mind Mapping }\end{array}$ \\
\hline (7) & $\begin{array}{l}\text { Process Improvement Techniques } \\
(\text { PIT })\end{array}$ & $\begin{array}{l}\text { (24) Workflow Management; (25) Business Process Re-engineering; (26) JIT (Just- } \\
\text { in-Time);(27) TQM (Total Quality Management); (28) Lean Process Technology }\end{array}$ \\
\hline (8) & $\begin{array}{l}\text { Innovative Project Management } \\
\text { Techniques (IPMT) }\end{array}$ & $\begin{array}{l}\text { (29) Pre-project Management Phase; (30) Development Project Management Phase; } \\
\text { (31) Management Phase ; (32) Learning From Experience; (33) Project Portfolio } \\
\text { Management }\end{array}$ \\
\hline (9) & $\begin{array}{l}\text { Design Management Techniques } \\
\text { (DMT) }\end{array}$ & $\begin{array}{l}\text { (34) Design Management Expanding in Scope;(35) CAD systems; (36) RP (Rapid } \\
\text { Prototyping); (37) Usability Approaches; (38) VA(Value Analysis) }\end{array}$ \\
\hline (10) & $\begin{array}{l}\text { Business Creation Techniques } \\
\text { (BCT) }\end{array}$ & $\begin{array}{l}\text { (39) Virtual Incubators ;(40) Spin-Off from Research to Market; (41) Computer-Aided } \\
\text { Business Simulation Games; (42) Entrepreneurship; (43) The Business Plan }\end{array}$ \\
\hline
\end{tabular}

Nanotechnology Sector in Mexico (NSM). We made a documentary study to determine the main factors that defines and affects the NSM, selecting 23 relevant documents from 100 articles with a detailed description on this topic and its relation with MIN. After this, we determined the main factors that defines and affects the NSM, asking in the focus group 1 among academic specialized in the topic, what MIN Technique they would suggested from the Table 2, for each article, creating and grouping at the same time, the main variables that defines and affects the NSM. The results are shown in Table 3 . 
Table 3: The NSM and its relationship with MIN. Focus Group: 1.

\begin{tabular}{|c|c|c|c|c|}
\hline No. & Year & $\begin{array}{l}\text { Author } \\
\text { s }\end{array}$ & The main variables that defines and affects the NSM & $\begin{array}{c}\text { MIN } \\
\text { Technique } \\
\text { Suggested } \\
\text { by } \\
\text { Academic } \\
\text { Vision } \\
\end{array}$ \\
\hline 1 & 2016 & [13] & Willingness to buy (m\&b); Risk \& Security (r\&s) & (3); (4) \\
\hline 2 & 2016 & [14] & $\begin{array}{l}\text { Policy Environments and Governance (r\&p); Environment\& Sustainability(sus); } \\
\text { Business Activity }(\mathbf{m} \& \mathbf{b})\end{array}$ & $\begin{array}{l}(1) ;(2) ;(3) ; \\
(10)\end{array}$ \\
\hline 3 & 2014 & [15] & Knowledge Management (kmg) & (1) \\
\hline 4 & 2014 & [6] & $\begin{array}{l}\text { Knowledge Management (kmg), Regulation \& Policies (r\&p); Nanotechnology } \\
\text { Infrastructure (r\&c); Risk \& Security (r\&s); Competitiveness (cmp); IR\&D (ir\&d) }\end{array}$ & $\begin{array}{l}(\mathbf{1}) ;(\mathbf{5}) ; \\
(\mathbf{8}) ;(\mathbf{1 0})\end{array}$ \\
\hline 5 & 2013 & [2] & Regulation \& Policies (r\&p);relationship government-univerisies-firms (hex) & (10) \\
\hline 6 & 2013 & [16] & Human Risk (r\&s), Competitiveness (cmp) & (10) \\
\hline 7 & 2013 & [17] & $\begin{array}{l}\text { Knowledge Management (kmg), Regulation \& Policies (r\&p); Nanotechnology } \\
\text { Infrastructure (r\&c); Risk \& Security (r\&s), IR\&D (ir\&d) }\end{array}$ & $(\mathbf{1}) ;(\mathbf{8}) ;(\mathbf{1 0})$ \\
\hline 8 & 2012 & [18] & $\begin{array}{l}\begin{array}{l}\text { Knowledge Management }(\mathbf{k m g}) \\
(\mathbf{r \& s}), \text { Competitiveness }(\mathbf{c m p})\end{array}\end{array}$ & (1); (2); (10) \\
\hline 9 & 2010 & [19] & Human Risk (r\&s); New Nanoproducts (nmp) & $(6) ;(7)$ \\
\hline 10 & 2010 & [20] & Consumer Acceptance $(\mathbf{m} \& \mathbf{b})$; Risk Governance $(\mathbf{r} \& \mathbf{p})$ & (10) \\
\hline 11 & 2010 & [4] & $\begin{array}{l}\text { Regulation \& Policies } \quad(\mathbf{r \& p}) ; \\
\text { Nanotechnology Infrastructure }(\mathbf{r \& c}) ;\end{array}$ & (10) \\
\hline 12 & 2010 & [7] & $\begin{array}{l}\text { Knowledge Management }(\mathbf{k m g}) \text {; Regulation \& Policies }(\mathbf{r \& p}) \text {;Competitiveness }(\mathbf{c m p}) ; \\
\text { [Collaboration Networks + Relationship between private and public sector+ Financing } \\
+ \text { Intellectual Property Rights]( } \mathbf{m} \& \mathbf{b}) \text {; Environment\& Sustainability (sus); New } \\
\text { Nanomaterials (nmp) }\end{array}$ & $\begin{array}{l}(1) ;(2) ;(3) ; \\
\quad(10)\end{array}$ \\
\hline 13 & 2009 & [21] & $\begin{array}{l}\text { Societal Dimensions (sus); Collaboration Strategies (m\&b) ; Regulation \& Policies } \\
(\mathbf{r \& p}) \text {; Share Publication among Universities (kmg) }\end{array}$ & $(\mathbf{1}) ;(3) ;(4)$ \\
\hline 14 & 2009 & [22] & Regulations \& Policies(r\&p); Network Collaboration (m\&b); & (4); (10) \\
\hline 15 & 2009 & [23] & $\begin{array}{l}\text { Sharing results and knowledge among Universities }(\mathbf{k m g}) \text {; Regulations \& Policies } \\
(\mathbf{r \& p})\end{array}$ & $(1) ;(10)$ \\
\hline 16 & 2008 & [24] & Risk Management \& Safety (r\&s); Regulation \& Policies (r\&p) & (10) \\
\hline 17 & 2008 & [25] & $\begin{array}{l}\text { Regulation \& Policies (r\&p); relationship among government-universities-companies- } \\
\text { society (hex) }\end{array}$ & (10) \\
\hline 18 & 2007 & [10] & $\begin{array}{l}\text { Knowledge Management }(\mathbf{k m g}) \text {, Regulation \& Policies }(\mathbf{r \& p}) \text {; Nanotechnology } \\
\text { Infrastructure }(\mathbf{r} \& \mathbf{c}) \text {; Consumer Acceptance }(\mathbf{m} \& \mathbf{b}) \text {; Competitiveness }(\mathbf{c m p}) ; \mathrm{R} \& \mathrm{D} \\
\text { (ir\&d) }\end{array}$ & $(1) ;(2) ;(10)$ \\
\hline 19 & 2007 & [26] & Regulation \& Policies $(\mathbf{r \& p})$ & (10) \\
\hline 20 & 2006 & [27] & New Nano materials+ New Nanoproducts (nmp) & $(2) ;(3)$ \\
\hline 21 & 2005 & [28] & $\begin{array}{l}\text { [Patents+ Commercialization] (m\&b); Competitiveness (cmp); Lifecycle Products } \\
(\mathbf{n m p})\end{array}$ & $(2) ;(7) ;(9)$ \\
\hline 22 & 2005 & [29] & Nanomaterials different products inventory(nmp) & $(6) ;(7) ;(9)$ \\
\hline 23 & 2003 & [1] & Competitiveness (cmp) & (10) \\
\hline
\end{tabular}

The name of the NSM variables proposed for the focus group 1, were: Competitiveness (com); Linkage government-university-firm (hex); Innovation, Research and Development (ir\&d); Knowledge Management ( $k m g$ ); Marketing and Business $(m \& b)$; New Nanomaterials and Nanoproducts $(n m p)$; Resources and Capacities $(r \& c)$; Regulations\& Policies $(r \& p)$; Risk \& Safety $(r \& s)$; Sustainability (sus) (see Table 4).All the concepts of each NSM variables were explained along the focus group process. This represents the specialist of the academic vision. 
Table 4. NSM variables proposed as are mentioned for each author analyzed. Source: own.

\begin{tabular}{|c|c|c|c|c|c|c|c|c|c|c|c|c|c|c|c|c|c|c|c|c|c|c|c|c|}
\hline \multirow{2}{*}{$\begin{array}{c}\text { NSM } \\
\text { Var }\end{array}$} & \multicolumn{24}{|c|}{ Number of Author (according Table 3) } \\
\hline & [1] & [2] & [4] & [6] & [7] & {$[10]$} & {$[13]$} & [14] & [15] & {$[16]$} & {$[17]$} & {$[18]$} & [19] & {$[20]$} & [21] & {$[22]$} & [23] & {$[24]$} & [25] & {$[26]$} & {$[27]$} & {$[28]$} & [29] & TOT \\
\hline cmp & $\mathrm{x}$ & & $\mathrm{X}$ & $\mathrm{X}$ & $\mathrm{X}$ & $\mathrm{x}$ & & & & $\mathrm{x}$ & & $\mathrm{x}$ & & & & & & & & & & $\mathrm{x}$ & & 8 \\
\hline hex & & $\mathrm{X}$ & & & & & & & & & & & & & & & & & $\mathrm{x}$ & & & & & 2 \\
\hline$i r \& d$ & & & & $\mathrm{X}$ & & $\mathrm{x}$ & & & & & $\mathrm{x}$ & & & & & & & & & & & & & 3 \\
\hline kmg & & & & $\mathrm{X}$ & $\mathrm{X}$ & $\mathrm{x}$ & & & $\mathrm{x}$ & & $\mathrm{x}$ & $\mathrm{x}$ & & & $\mathrm{x}$ & & $\mathrm{X}$ & & & & & & & 8 \\
\hline$m \& b$ & & & $\mathrm{X}$ & & $\mathrm{X}$ & $\mathrm{X}$ & $\mathrm{X}$ & $\mathrm{X}$ & & & & $\mathrm{X}$ & & $\mathrm{X}$ & $\mathrm{X}$ & $\mathrm{X}$ & & & & & & $\mathrm{X}$ & & 10 \\
\hline$n m p$ & & & & & $\mathrm{X}$ & & & & & & & & $\mathrm{X}$ & & & & & & & & $\mathrm{X}$ & $\mathrm{X}$ & $\mathrm{X}$ & 5 \\
\hline$r \& c$ & & & $\mathrm{X}$ & $\mathrm{X}$ & & $\mathrm{X}$ & & & & & $\mathrm{x}$ & & & & & & & & & & & & & 4 \\
\hline$r \& p$ & & $\mathrm{X}$ & $\mathrm{X}$ & $X$ & $\mathrm{X}$ & $\mathrm{X}$ & & $\mathrm{X}$ & & & $\mathrm{X}$ & & & $\mathrm{X}$ & $\mathrm{X}$ & $\mathrm{X}$ & $\mathrm{X}$ & $\mathrm{X}$ & $\mathrm{X}$ & $\mathrm{X}$ & & & & 14 \\
\hline$r \& s$ & & & & $X$ & & & $\mathrm{X}$ & & & $\mathrm{X}$ & $\mathrm{X}$ & $\mathrm{X}$ & $\mathrm{X}$ & & & & & $\mathrm{X}$ & & & & & & 7 \\
\hline sus & & & & & $\mathrm{X}$ & & & $\mathrm{X}$ & & & & & & & $\mathrm{X}$ & & & & & & & & & 3 \\
\hline & & & & & & & & & & & & & & & & & & & & & & & Total & 64 \\
\hline
\end{tabular}

After that, we proceeded to compare these results with the empirical point of view among the specialists (nanotechnology managers and researchers) in the practice as members of the focus group 2 to determine the level of importance of each NSM variables. To achieve this, we used the AHP (also known as a Saaty's Theorem [30]). This represents the specialist of the empirical vision. See Table 5.

Table 5: AHP or Saaty's Theorem.Focus group: 2.

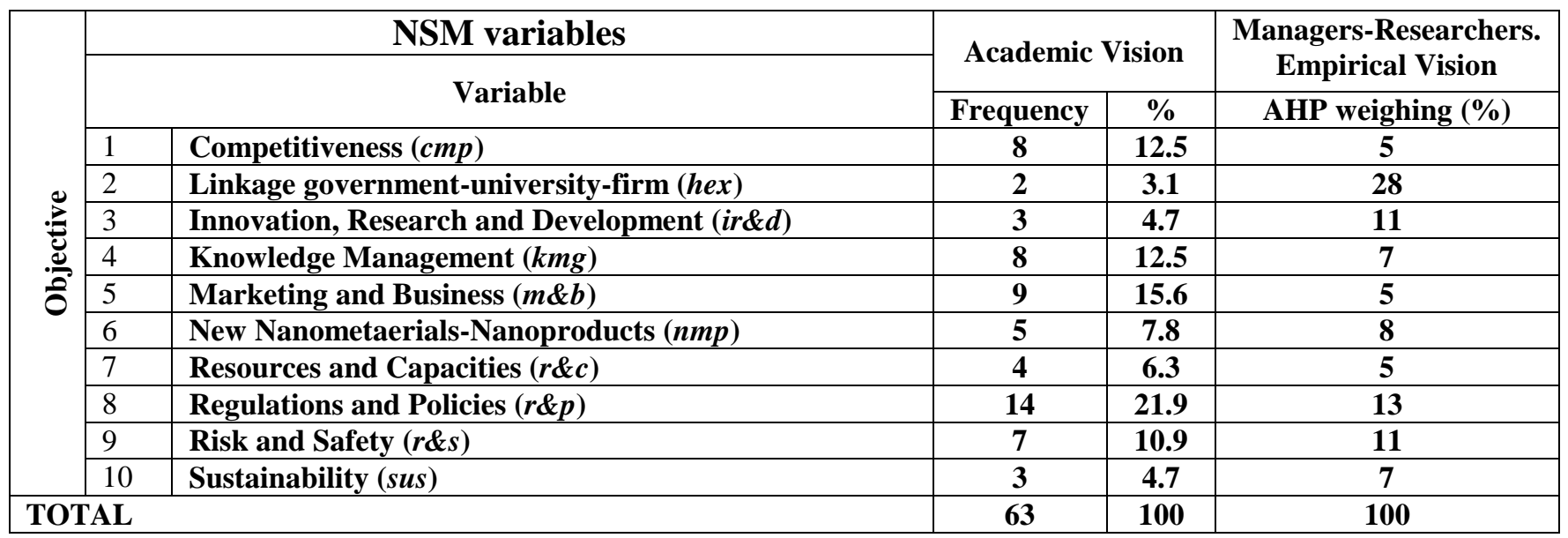

Finally, our conceptual model of MIN in NSM to get more COM, is shown in Figure 1. 


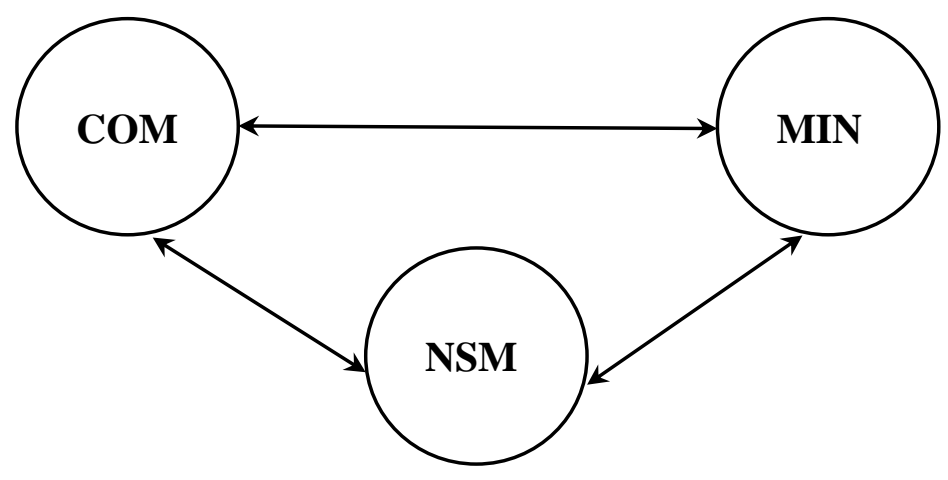

Fig. 1: The conceptual model of MIN in NSM to get more COM.

The proposal of questionnaire is shown in Table 6 .

Table 6: The proposal of questionnaire.

\begin{tabular}{|c|c|c|c|}
\hline $\begin{array}{l}\text { Fa } \\
\text { ct } \\
\text { or }\end{array}$ & $\begin{array}{c}\text { Varia } \\
\text { ble }\end{array}$ & Indicator & Author(s) \\
\hline \multirow{8}{*}{$\begin{array}{l}\mathbf{C} \\
\mathbf{O} \\
\mathbf{M}\end{array}$} & LDT & $\begin{array}{l}\text { You are compromised to achieve the mission of your nanotechnology organization, change and innovation; they } \\
\text { communicate with their staff, motivate them in their development and overall well-being; they are aware of and } \\
\text { responds to their own growth opportunities. }\end{array}$ & \multirow{8}{*}{ [8] } \\
\hline & CVG & $\begin{array}{l}\text { You consider your nanotechnology organization knows its clients intimately, knows what creates its value and responds } \\
\text { with innovative proposals that ensure a memorable experience, follow the evolution of their needs and establish the } \\
\text { basis for a constant alignment with them }\end{array}$ & \\
\hline & STP & $\begin{array}{l}\text { You consider your nanotechnology organization ensures the fulfilment of its vision and mission; analysing their } \\
\text { environment, understanding their challenges, setting priorities, defining strategic objectives, aligning their resources and } \\
\text { capabilities to ensure their execution, monitoring and evaluating expected results }\end{array}$ & \\
\hline & CICD & $\begin{array}{l}\text { You consider the values of your nanotechnology organization lay the foundation for developing a culture focused on } \\
\text { change, innovation and continuous improvement that is reflected in the way staff organize and engage to generate new } \\
\text { ideas to respond to the challenges they face }\end{array}$ & \\
\hline & SCO & $\begin{array}{l}\text { You consider your nanotechnology organization assumes responsibility for the social and environmental environment in } \\
\text { which it operates. This commitment is reflected in its initiatives to reduce its environmental footprint, promote the } \\
\text { integral well-being of its personnel and respond to the social needs of its community. }\end{array}$ & \\
\hline & W\&I & $\begin{array}{l}\text { You consider your nanotechnology organization ensures the integration of all its staff through the creation of a shared } \\
\text { identity and responding to their physical and emotional needs in the workplace as well as in the communities where they } \\
\text { live }\end{array}$ & \\
\hline & KNW & $\begin{array}{l}\text { You consider your nanotechnology organization collects, organizes, shares and analyses knowledge through the use of } \\
\text { its resources and the skills of its staff, thereby generating the intellectual capital of the organization it capitalizes for the } \\
\text { improvement and innovation of its products, services and processes. }\end{array}$ & \\
\hline & AGY & $\begin{array}{l}\text { You consider your nanotechnology organization responds quickly, adaptively and flexibly to the changes that occur in } \\
\text { its internal and external environment. }\end{array}$ & \\
\hline \multirow{9}{*}{$\begin{array}{l}\text { M } \\
\text { IN }\end{array}$} & KMT & You consider your nanotechnology organization is practicing some or several Knowledge Management Techniques. & \multirow{9}{*}{ [12] } \\
\hline & MIT & You consider your nanotechnology organization is practicing some or several Market Intelligence Techniques (MIT) & \\
\hline & $\begin{array}{c}\mathbf{C \& N} \\
\mathbf{T}\end{array}$ & $\begin{array}{l}\text { You consider your nanotechnology organization is practicing some or several Cooperative and Networking Techniques } \\
\text { (C\&NT) }\end{array}$ & \\
\hline & $\begin{array}{l}\text { HRM } \\
\text { T }\end{array}$ & $\begin{array}{l}\text { You consider your nanotechnology organization is practicing some or several Human Resources Management } \\
\text { Techniques (HRMT) }\end{array}$ & \\
\hline & CDT & You consider your nanotechnology organization is practicing some or several Interface Management Techniques (IMT) & \\
\hline & IMT & $\begin{array}{l}\text { You consider your nanotechnology organization is practicing some or several Creativity Development Techniques } \\
\text { (CDT) }\end{array}$ & \\
\hline & PIT & You consider your nanotechnology organization is practicing some or several Process Improvement Techniques (PIT) & \\
\hline & IPMT & $\begin{array}{l}\text { You consider your nanotechnology organization is practicing some or several Innovative Project Management } \\
\text { Techniques (IPMT) }\end{array}$ & \\
\hline & DMT & You consider your nanotechnology organization is practicing some or several Design Management Techniques (DMT) & \\
\hline
\end{tabular}




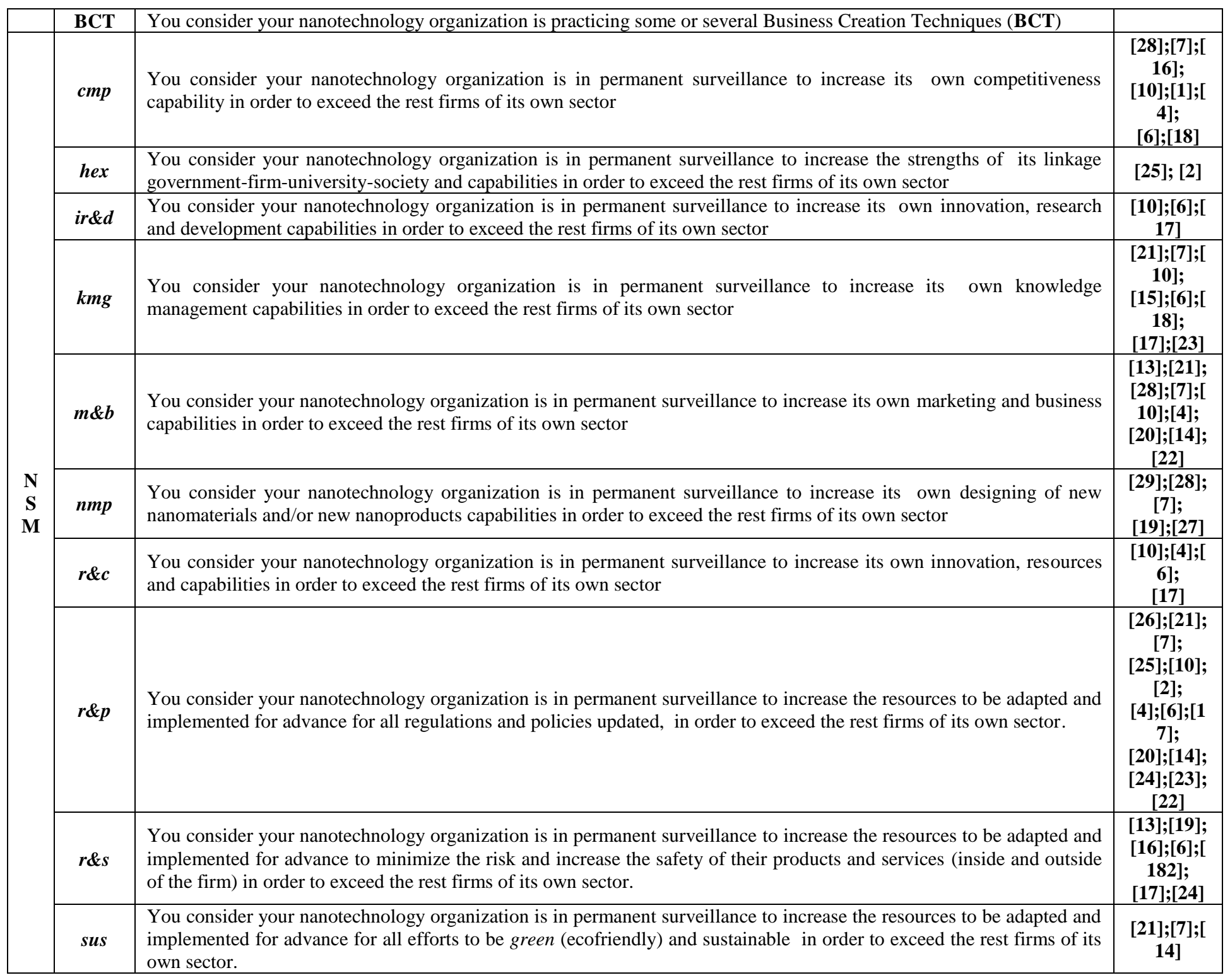

\section{Conclusions}

In this stage of the research, we answered: SQ1.-What are the main variables and indicators more appropriated to describe the MIN, NSM and COM factors?, through the results shown in Tables: 1-2-3-4-5. The SQ2.-What is the proposed general conceptual model? Is shown in Figure 1, and SQ3.-What is the proposal of questionnaire to be developed at a later stage? is shown in Table 6. So our RQ.- What is the conceptual model of the MIN in the companies belonging to the NSM, to get more COM? is answered too. Additionally, we made a proposal from both visions: the academic (see Table 3 for MIN Techniques. Focus group 1) and the empirical (see Table 5 for relative importance for NSM variables. Focus group: 2). The first results of the literature review (academic vision) vs. the managers and researchers point of view (empirical view), allows us to see important differences. For instance, despite the high frequency mentioned about the academic vision of the NSM variable: Regulations and Policies (r\&p), it only represents the $13 \%$ of relative importance for the nanotechnology managers and researchers; by other hand, the linkage of government-university-firm (hex), that is only mentioned in a 3\% for the academic vision, is pretty important for the nanotechnology managers and researchers in a $28 \%$. As you shall see, these results are not definitive, because this is the qualitative stage of this research. The following actions (scheduled to start in May 2017) shall be based on the quantitative methods as a part of the inferential statistic, considering 
the relationship direct and underlying of all the variables in interaction to disclose what are the most relevant variables in such interactions to explain how are affecting the field of the nanotechnology in Mexico.

\section{References}

[1] N. Ikezawa (2003). Competitiveness in High-Tech Fields and Nanotechnology [Online]. Available: https://www.nri.com/global/opinion/papers/2003/pdf/np200362.pdf

[2] E. Záyago-Lau, G. Foladori, R. P. Appelbaum, E. R. Arteaga-Figueroa, "Nanotechnology companies in Mexico: toward a first inventory," Estudios Sociales, vol. 21, no. 42, pp. 11-25, 2013.

[3] CONACYT (National Council of Science and Technology), "Special Program of Science and Technology 20012006. México, Conacyt," 2001.

[4] E. Záyago-Lau, G. Foladori, "Nanotechnology in Mexico: an uncertain development," Economía, Sociedad y Territorio, vol. 10, no. 32, pp. 143-178, 2010.

[5] Notimex (2015). Nanotecnología en México, un mercado de 1,500 mdd [Online]. Avaliable: http://www.manufactura.mx/tecnologia/2015/10/22/nanotecnologia-mexicana-vale-1500-mdd-especialistas

[6] G. C. Delgado-Ramos, "Nanotechnology in Mexico: Global trends and national implications for policy and regulatory issues," Technology in Society, vol. 37, pp. 4-15, 2014.

[7] G. Foladori, E. A. Figueroa, E. Záyago-Lau, "Relevance and Public Support of nanotechnology research in Mexico," Anduli, Revista Andaluza de Ciencias Sociales, no. 14, pp. 196-222, 2015.

[8] Portal PNC (Quality National Price) (2017). National Competitiveness Model [Online]. Available: http://www.pnc.org.mx/e-book-modelo-nacional-para-la-competitividad/

[9] OCDE (2015). Oslo Manual: Guidelines for Collecting and Interpreting Innovation Data (3rd ed.) [Online]. Available:

http://www.oecd.org/sti/inno/oslomanualguidelinesforcollectingandinterpretinginnovationdata3rdedition.htm

[10] K. Miyazaki, N. Islam, "Nanotechnology systems of innovation - An analysis of industry and academia research activities," Technovation, vol. 27, pp. 661-675, 2007.

[11] M. Dodgson, D. Gann, A. Salter, The Management of Technological Innovation Strategy and Practice. Oxford, Oxford University Press.

[12] European Commission Directorate-general for Enterprise, (2004). Innovation Management and Knowledge Driven Economy [Online]. Avalilable:

https://cordis.europa.eu/innovation-policy/studies/pdf/studies_innovation_management_final_report.pdf

[13] V. Sodano, M. T. Gorgitano, F. Verneau, "Consumer acceptance of food nanotechnology in Italy," British Food Journal, vol. 118, no. 3, pp. 714-733, 2016.

[14] OCDE Working Party on Nanotechnology (2016) [Online]. Available: http://www.oecd.org/sti/nano/reports.htm

[15] H. Purushotham (2014). Knowledge Management for Promoting Nanotechnology R\&D, Innovation and Commercialization [Online]. Available:

http://apctt.org/nanotech/sites/all/themes/nanotech/pdf/DR.\%20PURUSHOTHAM\%20-

$\% 20$ Final\%20Presentation\%20for\%20malaysia.pdf

[16] G. Foladori, "Nanotechnology Policies in Latin America: Risks to Health and Environment," Nanoethics, DOI 10.1007/s11569-013-0178-2, 2013.

[17] K. Savolaine, U. Backman, D. Brouwer, B. Fadeel, T. Fernandes, T. Kuhlbusch, R. Landsidel, I. Lynch, L. Pylkkänen, "Nanosafety in Europe 2015-2025: towards safe and sustainable nanomaterials and nanotechnology innovations," 2013.

[18] E. López-Vázquez, T.A. Brunner and M. Siegrist, "Perceived risk and benefits of nanotechnology applied to the food and packaging sector in México," British Food Journal, vol. 114, no. 2, pp. 197-205, 2012.

[19] A. G. Cattaneo, R. Gornati, E. Sabbioni, M. Chiriva-Internati, E. Cobos, M. R. Jenkins, G. Bernardinia, "Nanotechnology and human health: risks and benefits", Journal of Applied Toxicology, vol. 30, pp. 730-744, 2010.

[20] R. Ortwin, (2016). "Nanotechnology: Risk Governance," International Risk Governance Council, [Online]. Available: https://www.irgc.org/issues/nanotechnology/nanotechnology-risk-governance/

[21] L. Kay and P. Shapira, "Developing nanotechnology in Latin America," Journal of Nanoparticle Research, vol. 11, pp. 259-278, 2009.

[22] Red Venezolana de Nanotecnología, "Hacia un Plan Nacional de Nanotecnología”, 2009. 
[23] Ch. Chi-Fai, W. Shiuan-Huei and T. Gow-Chin, "The development of regulations for food nanotechnology," Journal of Economic Psychology 30, pp. 344-357, 2009.

[24] G. E. Marchant, D. J. Sylvester, K. W. Abbott, "Risk Management Principles for Nanotechnology," Nanoethics, vol. 2, pp. 43-60, 2008

[25] CIMAV (Centre of Advanced Materials Research) (2016). "Diagnóstico y Prospectiva de la Nanotecnología" [Online].

Available: http://www.nanored.org.mx/documentos/diagnostico\%20y\%20prospectiva\%20nanotecnologia\%20en\%20mexico.pd $\mathrm{f}$

[26] A.D. Romig Jr., A. B. Baker, J. Johannes, T. Zipperian, K. Eijkel B. Kirchhoff, H.S. Mani, C.N.R. Rao, S. Walsh, "An introduction to nanotechnology policy: Opportunities and constraints for emerging and established economies," Technological Forecasting \& Social Change, vol. 74, pp. 1634-1642, 2007.

[27] European Nanotechnology Gateway, "Nanotechnology in Consumer Products," (2006) [Online]. Available: http://www.nanowerk.com/nanotechnology/reports/reportpdf/report64.pdf

[28] Ch. M. Shea, "Future management research directions in nanotechnology: A case study," Journal Engineering Technology Management, vol. 22, pp. 185-200, 2005.

[29] A. Maynard, E. Michelson (2016), "The Nanotechnology Consumer Products Inventory," Woodrow Wilson International Center for Scholars and The Pew Charitable Trusts [Online]. Available, at: http://www.nanotechproject.org/process/files/2753/consumer_product_inventory_analysis_handout.pdf

[30] T. L. Saaty, "Decision making with the analytic hierarchy process," International Journal Services Sciences, vol. 1, no. $1,2008$. 